\title{
Social development of young children in different cultural systems
}

\author{
Jutta Kienbaum
}

Gisela Trommsdorff 
ABSTRACT Ninety-six 5-year-old girls and boys and their mothers $(\mathrm{n}=87)$ participated in a cross-cultural study on prosocial behaviour in Germany and the former USSR. Each child was observed interacting with a playmate who appeared to be sad. The mothers' educational belief systems were examined on the basis of: (i) a semi-projective instrument (So-Sit) depicting everyday conflicts between mother and child; (ii) an interview on a recent conflict. The intensity of prosocial behaviour was higher in German girls than in German boys or Russian girls. More Russian boys than girls showed at least some kind of prosocial behaviour. Russian mothers described their handling of conflicts as more harmonious than German mothers, whereas sex differences occurred within each culture. The results are discussed with regard to the impact of different child-rearing belief systems in individualistic versus collectivist cultures on the social behaviour of children.

RESUMÉ 96 filles et garçons âgés de cinq ans et leurs mères $(\mathrm{n}=87)$ ont participé à une étude de comparaison culturelle du comportement pro-social en Allemagne et en ex-URSS. Chaque enfant était individuellement observé au cours d'une rencontre avec un camarade de jeu qui était triste. Les systèmes de croyances d'éducation des mères ont été étudiés au moyen d'un instrument semi-projectif (So-Sit) relevant les conflits quotidiens entre la mère et l'enfant, et grâce à une interview de la mère sur une conflit récent. L'intensité des comportements pro-sociaux s'est avérée plus importante chez les filles allemande que chez les filles russes ou les garçons allemandes, tandis que plus de garçons russes que de filles ont montré au moins une sorte de comportement serviable. Les mères russes ont décrit la gestion de conflits plus harmonieux que les mères allemandes, bien qu'on note des différences suivant le sexe de l'enfant dans chaque culture. Les résultats sont discuté par rapport à l'importance de différents concepts d'éducation pour le comportement social de l'enfant dans les cultures individualistes ou collectivistes. 
RESUMEN En una investigación transcultural sobre la conducta prosocial llevada a cabo en Alemania y en la antigua USSR, participaron 96 niños y niñas de 5 años y sus madres $(\mathrm{n}=87)$. Se observó a cada niño interactuando individualmente con un compañero de juego triste. Los sistemas de creencias de las madres se estudiaron con un instrumento semi-proyectivo (So-Sit) que planteaba conflictos cotidianos entre una madre y su hijo, y además contestaron a una entrevista relacionada con una situación conflictiva reciente. La intensidad de la conducta prosocial fue mayor en las niñas alemanas que en los niños alemanas y las niñas rusos. Hubo más niños rusos que niñas rusas que dieran muestras de algún tipo de conducta prosocial. Las madres rusas describieron su manejo de los conflictos como más armonioso que el de las madres alemanas, aunque en el interior de cada uno de los grupos culturales se hallaron diferencias ligadas al sexo. Los resultados se discuten en términos del impacto de las diferentes creencias en culturas colectivistas e individualistas sobre la conducta social infantil.

\section{Introduction}

The culture in which a child grows up has a major impact in shaping the child's personality, including central dimensions of his/her social development such as empathy, prosocial behaviour and competition or cooperation. Cultures provide the values and the developmental niche' (Super \& Harkness, 1997) for a child's socialisation. The extent to which prosocial behaviours occur in different cultures varies considerably (Whiting \& Whiting, 1975). Eisenberg \& Mussen (1989) conclude that:

... children apparently are likely to develop high levels of prosocial behaviour if they are raised in cultures characterised by (1) parental and peer stress on consideration for others, sharing, and orientation toward the group, (2) a simple social organisation and/or a traditional, rural setting, (3) assignment to women of important economic functions, (4) living in an extended family, and (5) early assignment of tasks and responsibility to children. (p. 53)

Cultures are not homogenous entities and they vary in many respects. One dimension that has received much interest in recent years is the so-called 'individualism/collectivism' dimension (Triandis, 1989). In 'individualistic' cultures priority is given to the individual's interests and the person's independence and autonomy, whereas in 'collectivistic' cultures priority is given to the group's interests and conformity to group norms is pronounced. This concept has in the meantime been challenged by much criticism on account of the assumed unidimensionality (see for example Kagitcibasi, 1998). However, this differentiation of cultures along the line of 'individualism-collectivism' has considerable heuristic value which is especially useful for our study.

The present study attempts to compare samples from a special type of a collectivistic culture, the former Soviet Union, with a rather individualistic culture, Germany before unification. The Soviet Union is an interesting cultural context insofar as collectivism was 'implanted' by the revolution in 1917. This is very different from, say, the cultural traditions of China or Japan. 'Indoctrinating pre-school children with collectivism' (Radina, 1968, cited in Tudge, 1991, p. 128) was the most important task of pre-school in the Soviet Union. This goal was to be attained mainly by the formation of high moral qualities in the children. The 1982 pre-school programme stated that children should 'develop joint cooperation and mutual help in the course of play, kindness and a willingness to help one's comrades, and the means to regulate disagreements' (Vasil'eva, 1982, cited in Tudge, 1991, p. 128). Whole books were published on this topic, for example The Education of Moral Feelings in Older Pre-schoolers (Vinogradova, 1989) or Moral Education in Kindergarten (Netschajewa \& Markowaja, 1984). In summary, children were supposed to learn not to transgress rules, to obey adults, to 
co-operate and to help others and to take into account the needs and welfare of the group rather than of oneself. Considering the importance of prosocial behaviour as a most crucial component of education in the former USSR, it seems only natural to expect that children brought up in this system should show more helping behaviour than their peers from an individualistic culture. Of course, prosocial behaviour is valued everywhere, but it is rarely attached such importance by society as a whole. In line with this, the points mentioned above by Eisenberg \& Mussen (1989) are also more characteristic of the former Soviet Union than of Germany. The clear orientation towards the group, which was partly realised by assigning tasks and responsibilities to children living in an extended family, and the fact that nearly all women in the former USSR worked outside the home are all factors that would seem to favour the prosocial behaviour of Russian children.

Empirical data to test this assumption are non-existent. Indirect support comes from Bronfenbrenner's studies $(1967,1970)$, who investigated the willingness of American and Soviet school children to engage in antisocial behaviour. The results clearly indicated that Soviet children, compared with children in the USA, showed considerably more conformity to adult social norms and that they would refrain from behaviour their parents might disapprove of. However, this does not mean that these children also act more prosocially, for helping means to approach someone actively, which is qualitatively very different from not doing something grown-ups disapprove of. One purpose of the present study, therefore, was to compare prosocial behaviour in 5-year-old kindergarten children from the former USSR and Germany.

Another interesting question is how children learn to internalise cultural values or, to use Bronfenbrenner's (1979) terms, how are cultural values transmitted from the macro- to the micro level of society. In line with much of the literature on socialisation, we assume that one important means of transmission is the values and beliefs mothers hold about child rearing (see for example Trommsdorff, 1989; Super \& Harkness, 1997). We use the term 'beliefs' rather than 'child rearing style' because we did not study the actual behaviour of the mothers but asked them to verbally describe how they usually react in the case of everyday conflicts with their children. According to the above-mentioned differences in both cultural contexts, child rearing beliefs can be expected to differ between mothers in collectivist or individualistic cultures, thus reflecting the different value systems. While western industrialised cultures are oriented towards fostering independence and self-reliance in the child, child rearing in the former USSR focused on the child's obedience and accommodation to social expectations (Bronfenbrenner, 1970). Accordingly, another goal of the present study was to compare the child rearing belief systems of the children's mothers from the former USSR and Germany. More specifically, mothers' beliefs about how to deal with everyday conflicts in interaction with their child were to be compared. It was expected that in the collectivistic as compared with the individualistic context mothers would expect more obedience from their child. On this basis, predictions were made with regard to the quality of mother-child interactions, especially with regard to the degree of conflict. One may expect less conflict in a collectivist, norm-oriented context compared with an individualistic context which values independence and fulfilment of individual needs.

\section{Method}

\section{Subjects and Procedures}

The sample consisted of $n=965$-year-old-children from Konstanz, a middle sized town in southern Germany, and Moscow (24 girls and 24 boys in each culture, all of them attending kindergarten). Since not all mothers were willing to participate, their number was reduced to 
$n=42$ German and $n=45$ Russian mothers. The children were videotaped as they interacted individually with a young adult playmate who told them she was playing with her last and only two balloons. During the game, the playmate's balloon popped and she demonstrated her sadness (for a detailed description see Kienbaum, 1993, p. 68; Trommsdorff, 1995). The mothers filled out a semi-projective questionnaire (So-Sit; Komadt, 1989; see also Kienbaum \& Trommsdorff, 1998). The So-Sit depicts everyday conflicts between mother and child. The mothers were asked to describe how they would react, what their educational goal was, why they thought the child behaves in this manner and how the interaction would end. Additionally, an interview was conducted in which the mothers were asked to describe an everyday conflict they had actually experienced with their child.

\section{Coding of Responses}

Two independent observers, one from Germany and one from Russia, coded the videotaped prosocial behaviours. First, the rater measured whether prosocial behaviour occurred at all and, if so, what kind of prosocial act was shown (e.g. giving advice, verbal comforting, giving away the own balloon, ...). Second, a global rating of the intensity of prosocial behaviour was measured on a six point-scale $(1$, none; ...; 6 , very strong).

The answers of the mothers were analysed by a German and a Russian native speaker using a category system that had been developed at the University of Saarbrücken (Komadt, 1989). The 44 categories were reduced by means of a principal component analysis to six factors, three of them representing a harmonious and three a disharmonious interaction (see Appendix for a detailed description).

\section{Results}

The first step was to test how many children helped the playmate, regardless of the type of prosocial behaviour (Fig. 1).

Nearly all of the German girls and Russian boys and only a little more than half of the Russian girls and two-thirds of the German boys showed prosocial behaviour. The difference between Russian girls and boys reached statistical significance (Fisher's exact test, $p<0.05$ ).

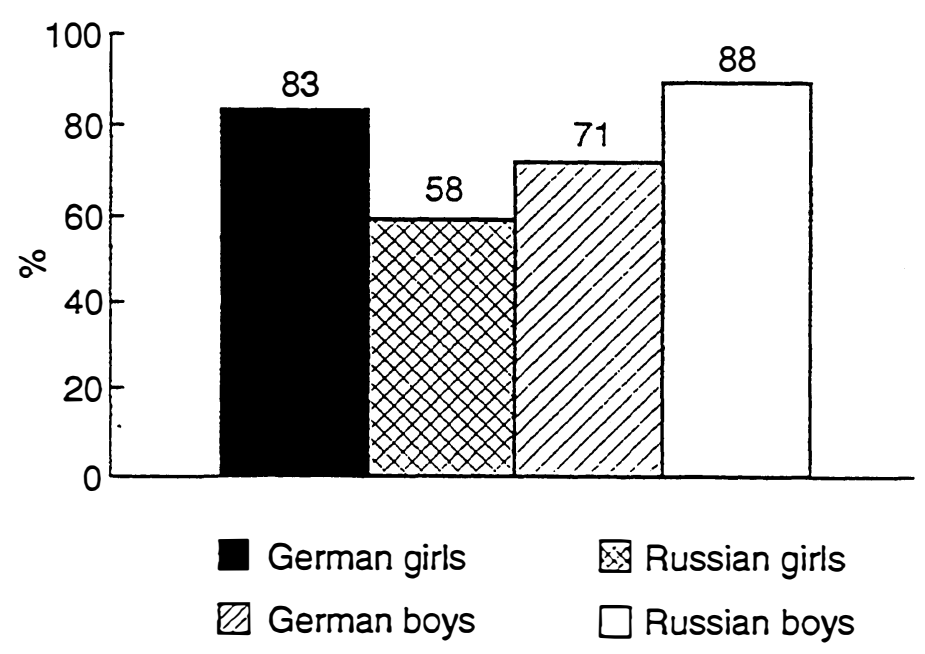

FIG. 1. 
TABLE I. Cultural and gender differences in the intensity of prosocial behaviour

\begin{tabular}{llll}
\hline $\begin{array}{l}\text { German children }(n=48) \\
\text { Female }(\text { mean } \pm S D)\end{array}$ & Male (mean \pm SD) & $\begin{array}{l}\text { Russian children }(n=48) \\
\text { Female }(\text { mean } \pm \text { SD) }\end{array}$ & Male (mean \pm SD) \\
\hline $3.8^{\mathrm{ab}} \pm 2.0$ & $2.6^{\mathrm{a}} \pm 1.5$ & $2.6^{\mathrm{b}} \pm 1.7$ & $3.0 \pm 1.1$ \\
\hline
\end{tabular}

Scale from 1 (no prosocial behaviour) to 6 (very strong prosocial behaviour).

${ }^{\text {ab }}$ Means with the same letter differ significantly at $p<0.05$.

TABLE II. Gender differences in mother-child interactions (Moscow)

\begin{tabular}{lccrr}
\hline & $\begin{array}{c}\text { Girls }(n=22) \\
\text { Mean } \pm \text { SD }\end{array}$ & $\begin{array}{c}\text { Boys }(n=23) \\
\text { Mean } \pm \text { SD }\end{array}$ & \multicolumn{1}{c}{ df } & \multicolumn{1}{c}{$\mathrm{t}$} \\
\hline Harmony 1 & $6.9 \pm 2.5$ & $5.6 \pm 2.2$ & 43 & $1.9^{\mathrm{a}}$ \\
Harmony 2 & $3.9 \pm 1.7$ & $4.0 \pm 2.1$ & 43 & -0.2 \\
Harmony 3 & $2.0 \pm 1.0$ & $1.7 \pm 1.3$ & 43 & 1.0 \\
Disharmony 1 & $1.4 \pm 0.7$ & $1.4 \pm 1.3$ & 43 & -0.9 \\
Disharmony 2 & $1.6 \pm 1.0$ & $1.9 \pm 1.6$ & 43 & -0.7 \\
Disharmony 3 & $2.4 \pm 1.3$ & $3.4 \pm 2.3$ & 43 & $-1.8^{\mathrm{a}}$ \\
\hline
\end{tabular}

${ }^{\mathrm{a}} p<0.10$, tendentially significant.

Since this does not say much about the quality of the helping behaviour, the intensity of the prosocial behaviour was analysed as a next step (Table I).

The German girls showed more intensive prosocial behaviour than the German boys and the Russian girls (Table I).

In a second step, the quality of mother-child interaction in conflict situations was compared (Fig. 2).

German and Russian mothers differed significantly in all six factors $(p<0.001$ in the disharmony factors and in 'harmony 2 '; $p<0.05$ in the other two harmony factors). Russianmothers scored higher in harmonious interactions, whereas German mothers described their conflicts as more discordant. Russian mothers more often excused the misbehaviour of the child because it cannot be made responsible ('every child wants to have everything s/he sees'), they expected the child to give in ('she obeys and we go home'), they were willing to give in a bit ('you can swing a few more times and then we'll go home') and they encouraged endocentric motivation. This term stems from Karylowski (1982) and means that mothers

$\square$ German mothers $\square$ Russian mothers

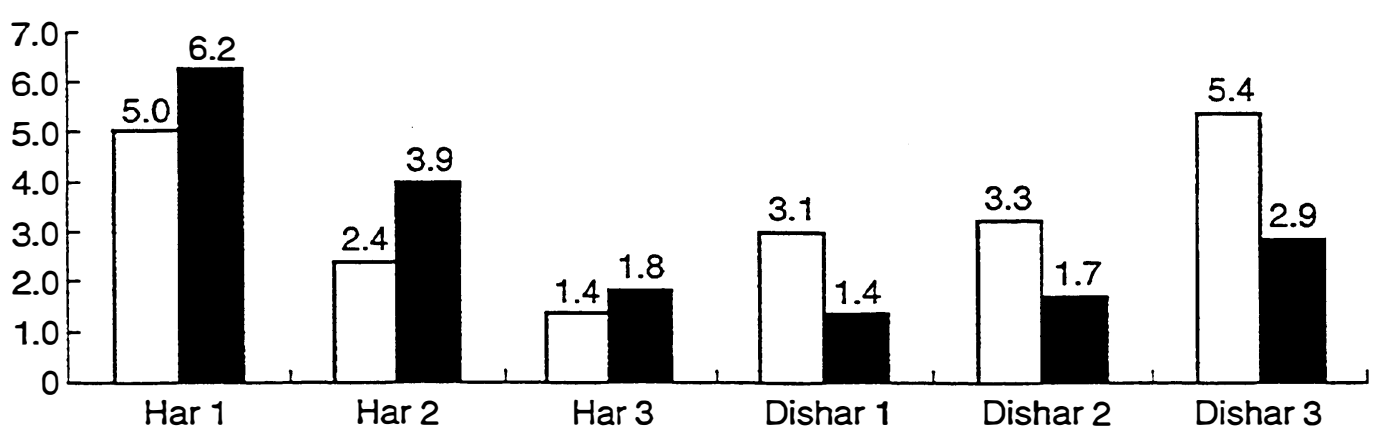

Note. Har $1=$ Harmony $1 ;$ Har $2=$ Harmony $2 ;$ Har $3=$ Harmony 3; Dishar $1=$ Disharmony 1 , Dishar 2 = Disharmony 2; Dishar 3 = Disharmony 3; (see appendix for description).

FIG. 2. 
TABLE III. Gender differences in mother-child interactions (Germany)

\begin{tabular}{lcccc}
\hline & $\begin{array}{c}\text { Girls }(n=21) \\
\text { Mean } \pm \text { SD }\end{array}$ & $\begin{array}{c}\text { Boys }(n=21) \\
\text { Mean } \pm \text { SD }\end{array}$ & df & $\mathrm{t}$ \\
\hline Harmony 1 & $4.8 \pm 2.4$ & $5.2 \pm 3.1$ & 40 & -0.5 \\
Harmony 2 & $2.8 \pm 1.8$ & $2.0 \pm 1.0$ & 40 & $1.9^{\mathrm{a}}$ \\
Harmony 3 & $1.4 \pm 0.8$ & $1.4 \pm 0.8$ & 40 & 0 \\
Disharmony 1 & $3.1 \pm 1.7$ & $3.1 \pm 1.4$ & 40 & 0 \\
Disharmony 2 & $3.1 \pm 1.8$ & $3.5 \pm 1.8$ & 40 & -0.7 \\
Disharmony 3 & $5.1 \pm 2.8$ & $5.8 \pm 3.8$ & 40 & -0.7 \\
\hline
\end{tabular}

${ }^{\mathrm{a}} p<0.10$, tendentially significant.

make moral appeals to norms ('don't, shame on you!'). In contrast, German mothers attributed the child's misbehaviour to defiance ('a child wants to test his/her limits'); both mother and child insisted more often on their points of view ('she will leave the room grumbling and bang the door'); the mothers reported a more negative effect ('I feel angry with my child') and the situations ended with less compromises.

The next step involved an analysis of gender differences within each culture.

Within the Russian group, (Table II) two trends occurred: more harmonious interaction in mother-daughter pairs than in mother-son pairs (harmony 1: positive attribution, positive affect, child obeys, mother claims for a later accomplishment of needs) and more disharmonious interaction in mother-son than in mother-daughter interactions (disharmony 3: negative attribution, perseveration of conflict, incompatibility of needs, child does not obey).

Within the German culture, (Table III) the only difference that approached significance occurred for the 'harmony 2' factor, which mainly measured mothers' empathic feelings for the child and a harmonious interaction. This was more often reported by German mothers about daughters than sons.

\section{Discussion}

In the present study, clear intercultural and intracultural differences occurred both in children's prosocial behaviour and in mother-child interactions in everyday conflicts. As for the prosocial behaviour, regardless of type, more boys than girls from Moscow showed at least some kind of prosocial intervention. With respect to quality, it turned out that the German girls showed more intensive prosocial behaviour compared with German boys and Russian girls.

The analyses of mother-child conflicts showed that Russian as compared with German mothers reported more harmony in their interaction with their children. Intracultural analyses of gender showed that in both cultures mothers tended to report more harmonious interactions in conflicts with their daughters than with their sons. At first sight, the results concerning the prosocial behaviour seem quite surprising, especially the fact that nearly $50 \%$ of the Russian girls did not make any attempt to help the sad playmate. Apparently, the goals of Soviet education for morality were not successful, at least for girls in the situation as studied here. The results for boys were somewhat different. Most boys showed at least some kind of intervention, though not a very intensive one. Intensity of prosocial behaviour was highest for German girls, an interesting fact in the light of theory that would predict less solidarity and helping behaviour in an individualistic as compared with a collectivist culture; in the former, priority should be given to goals of individual independence and autonomy. On the other hand, the analyses of the descriptions of mother-child interactions in conflicts confirmed the expectations: the mothers from the collectivist culture (the former USSR) reported more harmony and less conflict than mothers from the individualistic culture. This result is in line with recent data on mother-child interactions in east and west Germany, which also demonstrate a more harmonious and rule-oriented socialisation in east German families in contrast 
to a more conflicting mother-child interaction in west German families (Trommsdorff \& Komadt, 1999).

Thus, an interesting pattern emerges from the present study: on the one hand, mother-child interactions in a collectivist context are rather harmonious and cooperative while at the same time girls are reluctant to conform to helping norms.

These surprising results may be better interpreted when taking the intracultural gender differences into account. In both cultures, mothers reported more harmonious interactions with their daughters as compared with their sons. It is possible that this result means something different in the framework of an individualistic or a collectivist culture: mothers' empathy for the child and mothers' attempts to compromise in conflict situations may foster the development of prosocial behaviour in an individualistic culture. On the other hand, when the child's socialisation is characterised by values of norm orientation and obedience, the child may have difficulties in developing a concept of self-efficacy and individual responsibility for behaviour. The dominance of demands on obedience in the process of the child's socialisation may block activity in novel situations, even in such a situation when another person needs help. This interpretation corresponds to very similar results on Japanese children, who show strong distress in situations reflecting inner conflicts (Trommsdorff, 1995). It gains further support from the result that Russian boys score higher than Russian girls on the third 'disharmony' factor, which includes the mother's belief that a child is responsible for what he or she is doing, and that the child will actively protest in case of any conflicting needs. It seems that for children in a collectivist culture a certain socialisation experience can foster the development of prosocial behaviour; this experience seems to consist of encouraging a critical attitude towards conformity demands and actively arguing with a person in authority. Such socialisation experiences may encourage children in a collectivist culture to develop a sense of self-efficacy and, finally, act prosocially even in a situation that is not very common to them.

In the individualistic cultural context, other socialisation experiences prove more suitable for the development of prosocial behaviour. Here, the child's experience of mother's empathy in conflicting situations and the mother's endeavour to compromise promote more empathy-based prosocial interventions.

To summarise, the results indicate culture-specific effects of certain child rearing belief systems on the prosocial behaviour of children. It is interesting to note that in both cultures mothers reported more harmonious interactions with their daughters than with their sons. Apparently, mothers cross-culturally view girls according to sex stereotypes as easier to handle and with whom they struggle less for power. Nevertheless, the harmony subtypes in which girls exceeded boys were different in the two cultures; consisting of empathy for and harmony with the child in Germany and of views of the child as not responsible and obedient in the former USSR. Apparently, it would have been more advantageous for the Russian girls, at least as far as their prosocial behaviour is concerned, if their socialisation agents had encouraged more self-reliance and the development of concepts such as self-efficacy.

Of course, this study has limitations. First of all, the number of children investigated is small and not representative. Second, the type of situation we conducted is a very special one, namely the child being alone with a sad playmate, a young adult. We do not know how the children would have reacted if the same misfortune had happened to a person who is closer to the child, such as a parent or a sibling. This may have been of special importance for the Russian children, for in collectivism there is a sharper distinction between in-group and out-group than in individualism. Thus, although the children and the playmate were acquainted, they might not have perceived her as 'one of us'. Finally, there are far more factors that contribute to the development of prosocial behaviour in children, such as social competence, the child's self-concept and, most important, the ability to empathise. Ongoing 
research at the University of Augsburg is therefore focusing on shyness as one component of social competence and research at the University of Konstanz on the role of self-concept and self-efficacy in the development of empathy and prosocial behaviour. Beyond this, more research is needed in order to be able to specify the relevant factors in socialisation that may influence the empathic reactions and prosocial behaviour of young children. Both authors are therefore currently studying the effects of specific parental child rearing styles (as experienced by mothers, fathers and children) and of educators in kindergarten in order to understand the impact on the social development of children. By studying effects of child rearing experiences in different contexts and by taking into account interacting processes in the development of social behaviour, we hope to achieve a better understanding of how prosocial behaviour develops in children.

\section{References}

BRONFENBRENNER, U. (1967) Response to pressure from peers versus adults among Soviet AND American school children, International Journal of Psychology, 2, pp. 199-208.

BRoNFENBRENNER, U. (1970) Two Worlds of Childhood: US and USSR (New York, Russell Sage).

Bronfenbrenner, U. (1979) The Ecology of Human Development (Cambridge, Harvard University Press).

EIsenberg, N. \& Mussen, P.H. (1989) The Roots of Prosocial Behavior in Children (Cambridge, Cambridge University Press).

Kagrtcibasi, C. (1998) Human development: cross-cultural perspectives, in: J.G. AdAIR, D. BELANGER \& K.-L. DiON (Eds) Advances in Psychological Science, Vol. 1: Social, personal, and cultural aspects (Hove, Psychology Press/Erlbaum, Taylor and Francis).

KARYLOWSKI, J. (1982) Two types of altruistic behavior! Doing good to feel good or to make the other feel good, in: V. J. Derlaga \& J. GnZelaK (Eds) Co-operation and Helping Behaviour, pp. $397-413$ (New York, Academic Press).

KIENBAUM, J. (1993) Empathisches Mitgefuehl und prosoziales Verhalten deutscher und sowjetischer Kindergartenkinder (Regensburg, Roderer).

KIENBAUM, J. \& TROMMSDORFF, G. (1998) Mother-Child interaction and its effects on prosocial motivation in German and Soviet preschool children, poster presented at the XVth Biennial ISSBD Meetings, Berne, Switzerland, $1-4$ July, 1998.

KORNADT, H.J. (1989) Aggressivität und Erziehung im Kulturvergleich. Abschlußbericht über die im Rahmen der Hauptuntersuchung und mit Mitteln der VW-Stiftung durchgeführten Arbeiten (Saarbrücken, Universität des Saarlandes).

NetschajewA, W.G. \& Markowaja, T.A. (Eds) (1984) Nrawstwennoje wospitanie $w$ detskom sadu [moral education in kindergarten] (Moscow, Prosweschtschenie).

SUPER, C.M. \& HARKNESS, S. (1997) The cultural structuring of child development, in: J.W. BERRY, P.R. DASEN et al. (Eds) Handbook of Cross-cultural Psychology, Vol. 2, pp. 1-39 (Boston, Allyn \& Bacon).

TRIANDIS, H.C. (1989) Cross-cultural studies of individualism and collectivism, in: J.-J. BermanN (Ed.) Nebraska Symposium on Motivation: cross-cultural perspectives, pp. 41-133 (Lincoln, University of Nebraska Press).

TROMmSDORFF, G. (1989) Kulturvergleichende Sozialisationsforschung, in: G. TROMmSDORFF (Ed.) Sozialisation im Kulturvergleich, pp. 6-25 (Stuttgart, Enke Verlag).

TROMMSDORFF, G. (1995) Person-contact relations as developmental conditions for empathy and prosocial action: a cross-cultural analysis, in: T. KINDERMANn \& J. VALSINER (Eds) Development of Person-Context Relations, pp. 113-146 (Hillsdale, NJ, Erlbaum).

TROMMSDORFF, G. \& KORNADT, H.J. (1999) East and West German mothers' socialisation and their children's social development, paper presented at the Conference of the Deutsche Forschungsgemeinschaft, Jena, Germany.

TUDGE, J. (1991) Education of young children in the Soviet Union: current practice in historical perspective, The Elementary School Journal, 92(1), pp. 121-133.

WhItING, B.B. \& WhITING, J.W.M. (1975) Children of Six Cultures: a psychocultural analysis (Cambridge, MA, Harvard University Press).

VINOGRADOVA, A.M. (1989) Wospitanie nrawstwennich tschuwst u starschych doschkolnikow [The education of moral feelings in older preschoolers] (Moscow, Prosweschtschenie).

\section{Appendix}

Harmony 1:

Harmony 2: harmonising of needs; empathy with the child; mother feels an emotional burden; encouragement of self-reflection of the child; uncertainty in prediction of child behaviour.

Harmony 3: affective perspective-taking; mother permits the child to act according to his/her needs, endocentric motivation.

Disharmony 1: mother strictly sets limits; total rejection of child's needs.

Disharmony 2: demand for immediate obedience; mother feels angry with child.

Disharmony 3: negative attribution; perseverance of conflict; incompatibility of needs; active opposition of child; child opposes maternal aversion. 